\title{
Land Surface Phenology in the Tropics: The Role of Climate and Topography in a Snow-Free Mountain
}

\author{
Annia Susin Streher, ${ }^{1,2}$ * João Francisco Ferreira Sobreiro, ${ }^{2}$ Leonor Patrícia \\ Cerdeira Morellato, ${ }^{1,3}$ and Thiago Sanna Freire Silva ${ }^{1,2}$
}

\begin{abstract}
${ }^{1}$ Universidade Estadual Paulista (Unesp), Instituto de Biociências, Rio Claro, São Paulo, Brazil; ${ }^{2}$ Ecosystem Dynamics Observatory, Universidade Estadual Paulista (Unesp), Instituto de Geociências e Ciências Exatas, Rio Claro, São Paulo, Brazil; ${ }^{3}$ Laboratório de Fenologia, Universidade Estadual Paulista (Unesp), Instituto de Biociências, Rio Claro, São Paulo, Brazil
\end{abstract}

\begin{abstract}
Leaf phenology represents a major temporal component of ecosystem functioning, and understanding the drivers of seasonal variation in phenology is essential to understand plant responses to climate change. We assessed the patterns and drivers of land surface phenology, a proxy for leafing phenology, for the meridional Espinhaço Range, a South American tropical mountain comprising a mosaic of savannas, dry woodlands, montane vegetation and moist forests. We used a 14-year time series of MODIS/NDVI satellite ima-
\end{abstract}

Received 7 July 2016; accepted 16 January 2017; published online 6 March 2017

Electronic supplementary material: The online version of this article (doi:10.1007/s10021-017-0123-2) contains supplementary material, which is available to authorized users.

Authors contributions ASS, TSFS and LPCM conceived and designed the research questions; ASS processed and analysed the satellite imagery; JFS acquired and analysed climatological data; ASS, TSFS and LPCM analysed and discussed the results. ASS led the writing of the manuscript with significant input from all authors.

*Corresponding author; e-mail: annia.streher@gmail.com ges, acquired between 2001 and 2015, and extracted phenological indicators using the TIMESAT algorithm. We obtained precipitation data from the Tropical Rainfall Measuring Mission, land surface temperature from the MODIS MOD11A2 product, and cloud cover frequency from the MODIS MOD09GA product. We also calculated the topographic wetness index and simulated clear-sky radiation budgets based on the SRTM elevation model. The relationship between phenology and environmental drivers was assessed using general linear models. Temporal displacement in the start date of the annual growth season was more evident than variations in season length among vegetation types, indicating a possible temporal separation in the use of resources. Season length was inversely proportional to elevation, decreasing 1.58 days per $100 \mathrm{~m}$. Green-up and senescence rates were faster where annual temperature amplitude was higher. We found that water and light availability, modulated by topography, are the most likely drivers of land surface phenology in the region, determining the start, end and length of the growing season. Temperature had an important role in determining the rates of leaf development and the strength of vegetation seasonality, suggesting that tropical vegetation is also sensitive to latitudinal temperature changes, regardless of the elevational gradient. Our work improves the current understanding of 
phenological strategies in the seasonal tropics and emphasizes the importance of topography in shaping light and water availability for leaf development in snow-free mountains.
Key words: land surface phenology; seasonal environments; topoclimate; tropical mountain; environmental drivers; phenological indicators.

\section{INTRODUCTION}

Plants are finely tuned to the seasonality of their environment, and phenology has been considered a key element to track vegetation responses to climate change (Polgar and Primack 2011; Morellato and others 2016). Leaf phenology represents a major temporal component of ecosystem functioning, regulating processes such as carbon, water and energy exchange, forage availability, competition and coexistence (Gotelli and Graves 1996; Cleland and others 2007). Identifying patterns and constraints regulating leaf phenology, and how these mechanisms differ among vegetation types, is therefore critical for understanding vegetation dynamics and for accurately forecasting future changes on ecosystems (Peñuelas and others 2009; Polgar and Primack 2011).

Phenological events are considered highly plastic traits, as they reflect flexible responses to environmental triggers (Davies and others 2013). Leaf phenology triggers are well understood in temperate systems (Richardson and others 2006; Polgar and Primack 2011; Hwang and others 2014), but drivers are still under debate for tropical environments (Morellato and others 2013; Borchert and others 2015). In seasonal tropical environments, water and light availability have been identified as the main external factors directly or indirectly controlling vegetation seasonal rhythms, placing physiological and evolutionary constraints on the timing of phenological events (Wright and van Schaik 1994; Morellato and others 2000; Rivera and others 2002; Jolly and others 2005; Archibald and Scholes 2007; Pau and others 2013; Jones and others 2014; Bi and others 2015; Borchert and others 2015; Guan and others 2015). The seasonality in annual rainfall and radiation budgets often has different timings; when water is available, light is likely to limit the production of new leaves, and vice versa (Rivera and others 2002). According to Wright and van Schaik (1994), seasonal forests often receive $25-50 \%$ more photosynthetically active radiation (PAR) during the dry season, when water is potentially limiting, and $20-30 \%$ less PAR during the rainy season.

Plant strategies and adaptations to water and light limitations are directly related to the distinct life forms. Tree species have a better ability to access and store groundwater and are less dependent on the timing of rainfall (Borchert and others 2002; Rivera and others 2002; Archibald and Scholes 2007); thus, light-limited trees are predicted to produce new leaves during the season of maximal irradiance, regardless of moisture levels (Wright and van Schaik 1994; Borchert and others 2005; Calle and others 2010). Conversely, at a regional scale grasses are expected to have their maximum leaf area limited by hydraulic and architectural constraints, being more dependent on rainfall seasonality and soil water-holding capacity (Archibald and Scholes 2007), particularly in upland sites (Schimel and others 1991). Spatial and temporal variability in grasslands biomass accumulation are also driven by a combination of topography and fire history (Briggs and Knapp 1995; Reich and others 2001; Nippert and others 2006), and light limitation is usually more significant in unburned sites where considerable PAR is intercepted by detritus accumulation (Knapp and Seastedt 1986; Schimel and others 1991).

Elevational changes and topographic variability modulate the availability of abiotic resources such as light and water (Inouye and Wielgolaski 2013), influencing species distribution, biomass production and the timing of leaf production. Although there is a growing number of studies seeking to understand phenological changes across elevational ranges (Richardson and others 2006; Hudson Dunn and de Beurs 2011), direct investigation of tropical mountains has seldom been undertaken (Rocha and others 2016) and little is known about the relationship between topoclimatic conditions and leaf phenology in seasonal, snow-free tropical mountain environments (van Leeuwen and others 2013; Krishnaswamy and others 2014).

One of the most challenging aspects of understanding phenology in the tropics is the lack of long-term monitoring datasets (Chambers and others 2013; Morellato and others 2013, 2016). In this sense, historical remote sensing allows us to retrieve temporal information and a synoptic view of vegetation dynamics (Reed and others 2009). Known as land surface phenology (hereafter, LSP) (de Beurs and Henebry 2004), these remote sensing analyses are defined as the seasonal pattern of 
variation in vegetated land surfaces, being usually based on the calculation of spectral vegetation indices, derived from orbital sensors with high temporal resolution and moderate spatial resolution. The normalized difference vegetation index (NDVI) has been widely used to assess LSP, as it is capable of measuring photosynthetic activity and seasonal to interannual changes in leaf cover and canopy structure as a proxy for vegetation leaf phenology (Myneni and others 2007). Although the observed patterns are related to biological phenomena, LSP is distinct from traditional definitions of vegetation phenology, because it describes the seasonality of reflectance characteristics that are associated with stages of vegetation development (Henebry and de Beurs 2013), instead of specific events in a plant's life history.
The competing effects of light and water are also difficult to assess at regional ecosystem scales, and remote sensing can provide spatially explicit measurements of these factors that are fundamental to understand the effects of abiotic conditions on vegetation dynamics (Myneni and others 2007; Reed and others 2009). Here, we use a 14-year time series of MODIS/NDVI satellite imagery to characterize and understand the patterns of land surface phenology for the mosaic of highly diverse and endangered tropical seasonal forests and woodlands, grasslands and cerrado savannas distributed across the latitudinal and elevational gradients of the meridional portion of the Espinhaço Mountain Range, in south-eastern Brazil. We also combine satellite-based phenological, climatic and topographic information to evaluate how climate and

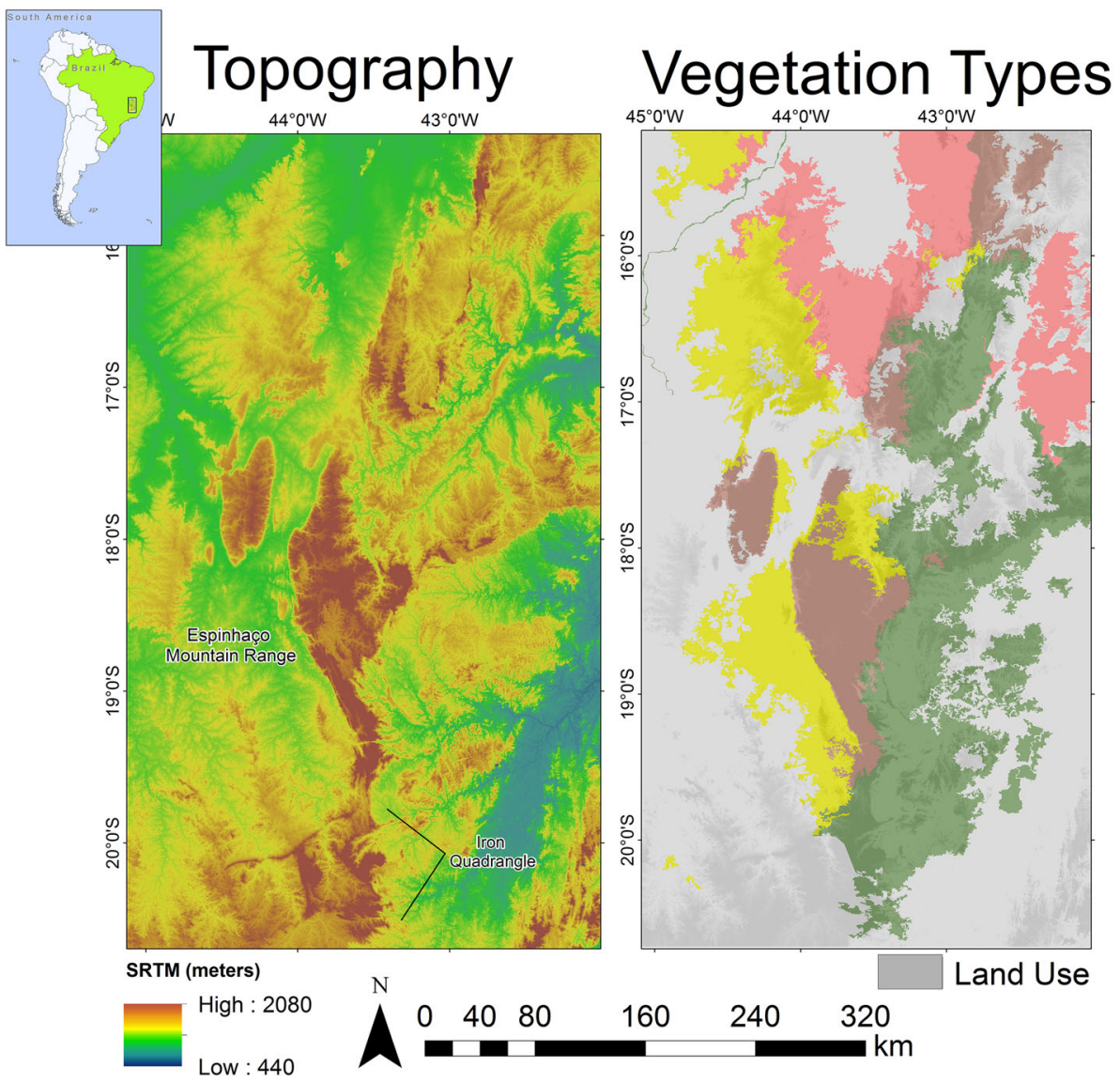

\section{Dry Woodlands}
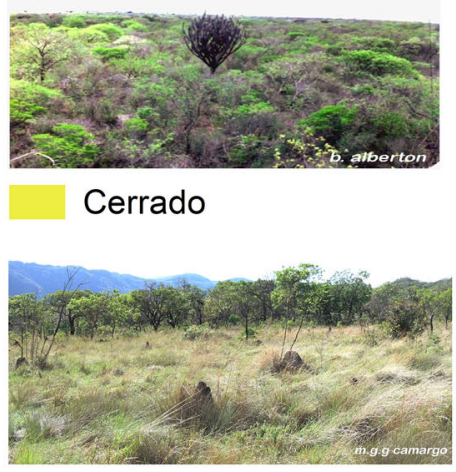

Montane Vegetation
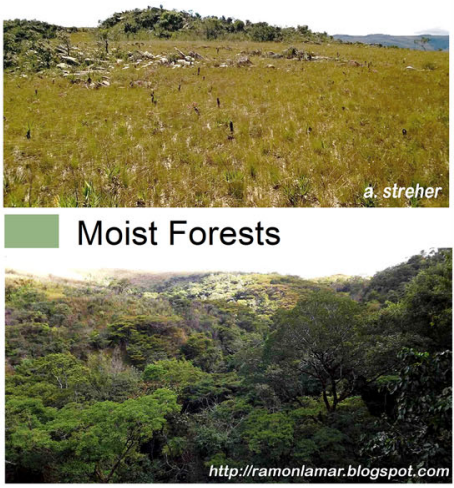

Figure 1. Overview of the topography and extent of the meridional portion of the Espinhaço Mountain Range, and the Iron Quadrangle, state of Minas Gerais, Brazil (left). On the right, the unique position of the Espinhaço Range as an ecotone of vegetation types: Atlantic rainforest (moist seasonal forest) to the east and south, cerrado (savanna) vegetation types to the west, dry woodlands in the north and, on the highlands, campos rupestres, a montane vegetation mosaic comprising mainly non-forest formations growing over sandy/rocky soils and rocky outcrops. Photographs: courtesy from Bruna Alberton (dry woodlands); Maria Gabriela Gutierrez Camargo (cerrado); Annia Streher (montane vegetation); Moist forest photograph taken from http://ramonlamar.blogspot.com. 
topography interact to shape water and light availability in the Espinhaço Range, thus driving the LSP of its several vegetation types.

\section{MethoDS}

We studied the meridional portion of the Espinhaço Range, including the "Iron Quadrangle" mountain formation, in the state of Minas Gerais, south-eastern Brazil (Figure 1). The Espinhaço Range (Cadeia do Espinhaço) is one of the most ancient landscapes on Earth, where different and highly diverse biomes converge, resulting in a complex biogeographic history and high levels of diversity and endemism (Fernandes 2016; Silveira and others 2016). This environment thus offers a unique opportunity to understand the effects of topoclimatic variability on LSP.

The Espinhaço Range spans approximately $1200 \mathrm{~km}$ in the $\mathrm{N}-\mathrm{S}$ direction, varying between 50 and $100 \mathrm{~km}$ in width along its length (Giulietti and Pirani 1988). The range emerged during Gondwana formation, nearly 640 Mya, evolving under prolonged tectonic stability and extreme weathering, with sedimentary rocks dating back to $1.8-1.75 \mathrm{Ga}$ (Schaefer and others 2016). The Iron Quadrangle is a major mineral province in Brazil, located south of the Espinhaço Range and covering an area of approximately $7000 \mathrm{~km}^{2}$, with rocks dating back to $2.5 \mathrm{Ga}$ ). Mean elevation in the studied area is over $1000 \mathrm{~m}$ above sea level, with peaks reaching 1800$2100 \mathrm{~m}$. The relief has rugged and sharp features, producing a wide diversity of soils and micro-environmental conditions (Giulietti and Pirani 1988; Schaefer and others 2016).

Moist forest vegetation occurs at the eastern and southern portions of the meridional Espinhaço Range, forming a transitional belt between the coastal humid Atlantic rainforest and the dryland vegetation of interior Brazil (de Lima and others 2015). The cerrado is a highly diverse neotropical savannas, including a wide range of vegetation types from open grasslands to woodlands with varying tree densities (Simon and others 2009), which can be found mainly at the western side of the Espinhaço Range. The northern portions of the Espinhaço Range are characterized by an ecotone of savannas, dry forests and caatinga, which are unique to NE Brazil (Portillo-Quintero and Sánchez-Azofeifa 2010), and broadly named here as dry woodlands. Finally, the Espinhaço highlands mountain vegetation are dominated by campos rupestres, a montane vegetation mosaic comprised of fire-prone grasses and shrubs growing on quartzite, sandstone or ironstone rocky outcrops, grasslands growing on sandy, stony or waterlogged soils, and patches of transitional vegetation such as cerrado, gallery forests and relictual hilltop forest patches occurring along the drainage network (Fernandes 2016; Silveira and others 2016).

Human disturbances in the region are associated with urbanization, deforestation and land appropriation for agriculture and Eucalyptus plantations, especially on the lowland regions (Silveira and others 2016). On the highlands, the major current threats are annual anthropogenic burnings to support the cattle industry, wood extraction, invasive species and, mainly in the Iron Quadrangle, opencast mining of gold, precious stones, and iron and manganese ore (Silveira and others 2016).

\section{Land Surface Phenology}

This study was based on a time series of 884 normalized difference vegetation index (NDVI) images derived from the Moderate Resolution Imaging Spectroradiometer (MODIS) sensor, acquired between 2002 and 2015, at 7-day intervals. We used the global NDVI dataset provided by the Institute of Surveying, Remote Sensing and Land Information (IVFL) of the University of Natural Resources and Applied Life Sciences (BOKU). This improved NDVI dataset uses as input the standard MOD13Q1 and MYD13Q1 NDVI 16-day maximum value composite products, from MODIS Aqua and Terra satellites (collection 5 products from NASA) (Huete and others 1999). MOD13Q1 and MYDI3Q1 NDVI are derived from the level-2G daily surface reflectance gridded data (MOD09 and MYD09 series) using the constrained view angle-maximum value composite (CV-MVC) compositing method. The BOKU dataset improves the standard NDVI products by filtering images for data noise and interpolating original observations to daily NDVI values using a Whittaker smoothing filter, which takes into account the quality of the observations according to the MODIS VI Quality Assessment Science Data Set (QA SDS) and the compositing day for each pixel (Vuolo and others 2012; Klisch and Atzberger 2016). The user can then choose the desired temporal aggregation step, such as our choice of 7-day intervals. This dataset has a spatial resolution of $250 \mathrm{~m}$ (Vuolo and others 2012; Klisch and Atzberger 2016).

NDVI is related to the photosynthetic capacity of vegetation and to biophysical variables such as the fraction of photosynthetically active radiation absorbed (fPAR) and fractional green cover (Tucker 1979), and is a measurement of the difference in light reflectance between the visible and near-infrared spectral regions: 
Table 1. Land Surface Phenology Metrics (Jönsson and Eklundh 2004), used to Describe Phenological Patterns Along the Espinhaço Range, SE, Brazil

\begin{tabular}{|c|c|c|}
\hline Phenological metrics & Description & Unit \\
\hline Start of the growing season (SOS) & $\begin{array}{l}\text { Represents the date of the start of the growing season. It is mea- } \\
\text { sured as an increase to } 20 \% \text { of the total seasonal amplitude, } \\
\text { measured in relation to the left side of the curve }\end{array}$ & Days \\
\hline End of the growing season (EOS) & $\begin{array}{l}\text { Represents the end date of the growing season. It is measured as a } \\
\text { decrease to } 20 \% \text { of the total seasonal amplitude, measured in } \\
\text { relation to the right side of the curve }\end{array}$ & Days \\
\hline Length of the growing season (LOS) & Length of time from SOS to EOS & Days \\
\hline Season amplitude (SA) & $\begin{array}{l}\text { Represents the strength of seasonality. It is measured as a differ- } \\
\text { ence between the highest value and the average of the left and } \\
\text { right minimum fitted values. Vegetation with stronger season- } \\
\text { ality will have higher SA values }\end{array}$ & Unitless \\
\hline Timing for mid-season (MID) & $\begin{array}{l}\text { Represents the proximate date of maximum photosynthetic } \\
\text { activity. It is measured as the mean value of dates for which the } \\
\text { left edge increased to } 80 \% \text { and the right edge decreased to } 80 \%\end{array}$ & Days \\
\hline Green-up rate $(\mathrm{GR})$ & $\begin{array}{l}\text { Represents the rate of increase of leaf flush events. It is measured } \\
\text { as the ratio of the difference between the left } 20 \text { and } 80 \% \text { levels } \\
\text { and the corresponding time difference. It is a ratio of NDVI } \\
\text { values per days }\end{array}$ & Unitless \\
\hline Senescence rate $(\mathrm{SR})$ & $\begin{array}{l}\text { Represents the rate of increase of senescence events. It is mea- } \\
\text { sured as the ratio of the difference between the right } 20 \text { and } \\
80 \% \text { levels and the corresponding time difference. It is a ratio of } \\
\text { NDVI values per days }\end{array}$ & Unitless \\
\hline
\end{tabular}

$$
\mathrm{NDVI}=\frac{\rho \mathrm{NIR}-\rho \mathrm{RED}}{\rho \mathrm{NIR}+\rho \mathrm{RED}}
$$

where $\rho$ is surface spectral reflectance. Higher NDVI values indicate increasing amounts of photosynthetically active vegetation cover. Roughly, NDVI values can be interpreted as: (a) negative values, approaching -1 , represent water bodies; (b) very low values of NDVI ( -0.1 to 0.1$)$ usually correspond to barren areas of rock or sand; (c) moderate values in the range of $0.1-0.3$ are associated with shrubs and grasslands; and d) high values, usually between 0.6 and 0.9 , are attributed to temperate or tropical forests. Although several vegetation indices exist in the specialized literature, NDVI was chosen for its lesser susceptibility to terrain illumination effects when compared to other indices (Teles and others 2015; Galvão and others 2016).

The TIMESAT 3.2 software suite was used to extract phenological metrics from the MODIS/ NDVI time series (Jonsson and Eklundh 2002, 2004). To further smooth noisy variations in the time series, the seasonal curves were fitted using a double logistic model (Jönsson and Eklundh 2004). A user-defined threshold of $20 \%$ of the seasonal amplitude, above the left minimum of the seasonal curve, was defined as the start of the growing season (SOS), and a similar threshold $(20 \%)$ was applied to the right minimum of the seasonal curve to define the end of the growing season (EOS). Amplitude is determined separately for each side of the curve, thus accounting for possible hysteresis in the seasonal response curves. This threshold was chosen by visual inspection of the fitted function for several random pixels representing each vegetation type, using TIMESAT's graphical interface, as the best compromise between capturing the maximum extent of the growing season without being overly influenced by minimum seasonal values, which can be strongly affected by noise (Jönsson and Eklundh 2004). The timing of the mid-season peak (MID) was then computed as the mean value of the curve values for which the left edge had increased to the $80 \%$ level and the right edge had decreased to the $80 \%$ level, as pre-defined by the TIMESAT algorithm. Season length (LOS) was defined as the time from the start (SOS) to the end (EOS) of the season. Green-up (GR) and senescence (SR) rates were calculated as the ratio of the difference between the left/right $20 \%$ and $80 \%$ of total curve amplitude levels and the corresponding time difference, also as pre-defined by the TIMESAT algorithm. Season amplitude (SA) was obtained as the difference between the peak value and the average of the left and right minimum values. All phenological metrics were extracted following Jönsson and Eklundh (2004) (Table 1; Figure 3). 


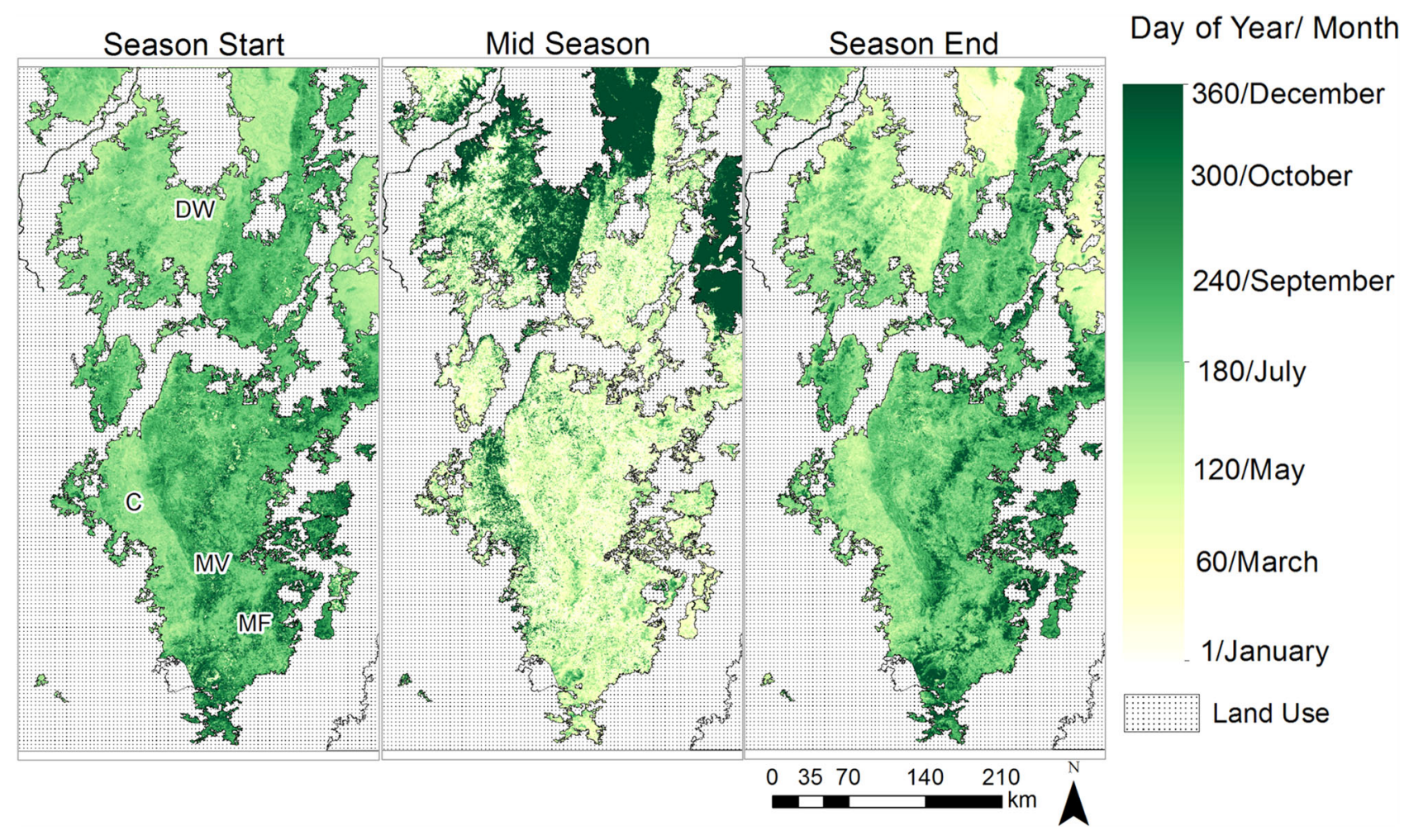

Figure 2. Mean Day of Year values for LSP metrics derived from a 14-year MODIS/NDVI time series in the meridional Espinhaço Mountain Range, south-eastern Brazil. Start of season (SOS), time of the mid-season (MID) and end of season (EOS) show a clear geographic pattern with similar trends in dates, with start, peak and end of growing season occurring later for higher-elevation vegetation. Also, the sharp discontinuity seen at lower latitudes is due to an abrupt change in topography leading to a transition between vegetation types. $D W$ dry woodlands, $C$ cerrado, $M V$ montane vegetation, $M F$ moist forest.

\section{Topoclimatic and Environmental Variables}

To characterize the geographic distribution of environmental drivers of plant phenology, we analysed remote sensing-derived temperature, precipitation and cloud cover frequency, and modelled topographical water availability and incoming solar radiation, based on terrain elevation data.

For temperature, we used the MODIS Terra Land Surface Temperature (LST) product (MOD11A2, version 5), which provides estimates of surface temperature at $1 \mathrm{~km}$ spatial resolution and 8-day time intervals. We used the MODISTools package in R (Tuck and others 2014), combined with the Modis Reprojection Tool by the NASA Land Process DAAC (https://lpdaac.usgs.gov/tools/modis_reproj ection_tool) to download, mosaic and reproject the MODIS LST time series from 2001 to 2015. We converted LST values to degree Celsius $\left({ }^{\circ} \mathrm{C}\right)$ and calculated the per-pixel daytime 90th percentile and nighttime 10th percentile of the time series to characterize the geographic and topographic distribution of temperature extremes. We then computed thermal amplitude as the difference between maximum and minimum temperature percentiles.

We characterized annual precipitation using data from the Tropical Rainfall Measuring Mission (TRMM), product $3 \mathrm{~B} 43$ version 7 , at $0.25^{\circ}$ $(\sim 27 \mathrm{~km})$ spatial resolution, covering the same period of the NDVI observations. The 3B43 product comprises estimated values of average monthly rainfall $\left(\mathrm{mm} \mathrm{h}^{-1}\right)$ inferred by an assimilation algorithm that ingests data from multiple sensors of the TRMM, as well as rain gauge data provided by the Global Precipitation Climatological Center (GPCC) and the Climate Assessment and Monitoring System (CAMS), and is produced by the National Oceanic Atmospheric Administration (NOAA). Image processing was carried out in ENVI 5.1 (Exelis Visual Information Solutions 2013), and precipitation values were converted from $\mathrm{mm} \mathrm{h}^{-1}$ to $\mathrm{mm}$ month ${ }^{-1}$. The agreement between monthly 


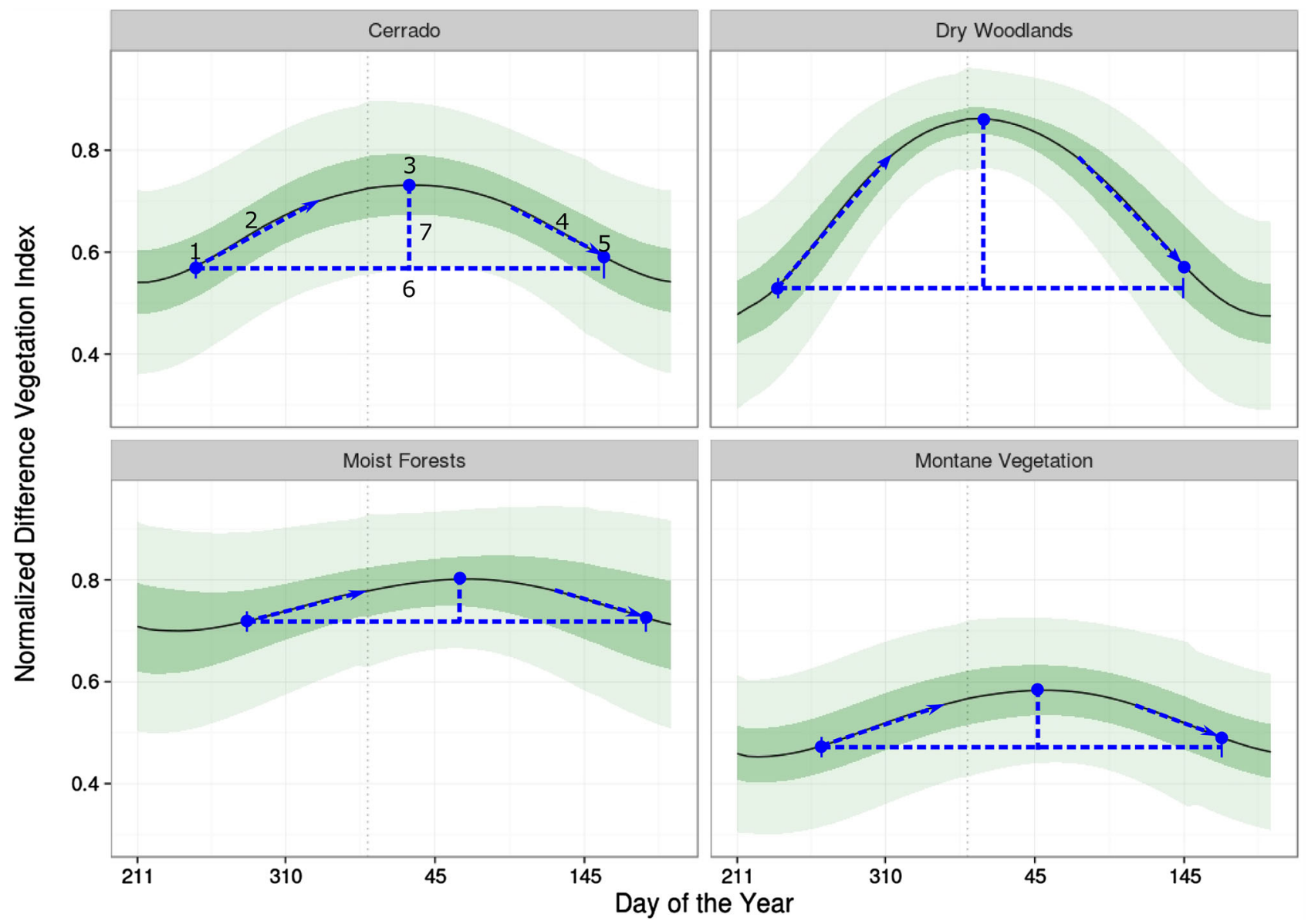

Figure 3. Phenological metrics extracted on a per-pixel basis from the NDVI/MODIS time series, through the TIMESAT program (Jönsson and Eklundh 2004). The black line represents the fitted time series; Dark green shading represents one standard deviation, while light green shading expresses two standard deviations. The start of the season (SOS) is given in Day of Year and is the time in which the left edge increased to a user-defined level (20\%), while the end of season (EOS), also given in Day of Year, is the time in which the right edge decreased to a user-defined level (20\%). Season length (LOS) is the number of days between SOS and EOS. The mid-season position (MID) is the mean date value between the points where the left edge of the curve increases to $80 \%$, and right edge decreases to $80 \%$. Season amplitude (SA) is the difference between the maximum value and the mean of the lowest fitted value for both SOS and EOS. Green-up (GR) and senescence (SR) rates are the ratio of increase for values between the 20 and $80 \%$ level of the right and left edges, respectively. The numbers indicate, respectively: 1-SOS; 2-GR; 3-MID; 4-SR; 5-EOS, 6-LOS; and 7-SA.

TRMM estimates and monthly ground observations from 112 weather stations distributed throughout the study area, covering the entire studied period, was of $R^{2}=0.96$ (Sobreiro and others 2015) and did not indicate any bias.

Elevation was derived from the Shuttle Radar Topography Mission (SRTM) 3-arcsec $(90 \mathrm{~m})$ dataset ( $\pm 15 \mathrm{~m}$ vertical accuracy), obtained from the Earth Explorer server of the United States Geological Survey (http://earthexplorer.usgs.gov/). Based on elevation, we derived the topographical wetness index (TWI), which represents a relative measure of potential long-term soil water storage capacity at a given site in the landscape. TWI was calculated using the SAGA GIS software, according to Beven and Kirbk (1979):

$$
\mathrm{TWI}=\ln \frac{a}{\tan B}
$$

where $a$ is the specific catchment (the cumulative upslope area draining through the cell, divided by its contour width) and $B$ is the local cell slope (Beven and Kirbk 1979). The specific catchment area describes the tendency of the site to receive water from upslope areas, and the local slope describes the tendency of the site to lose water through surface and subsurface run-off (Beven and Kirbk 1979). 


\section{Dry Woodlands}

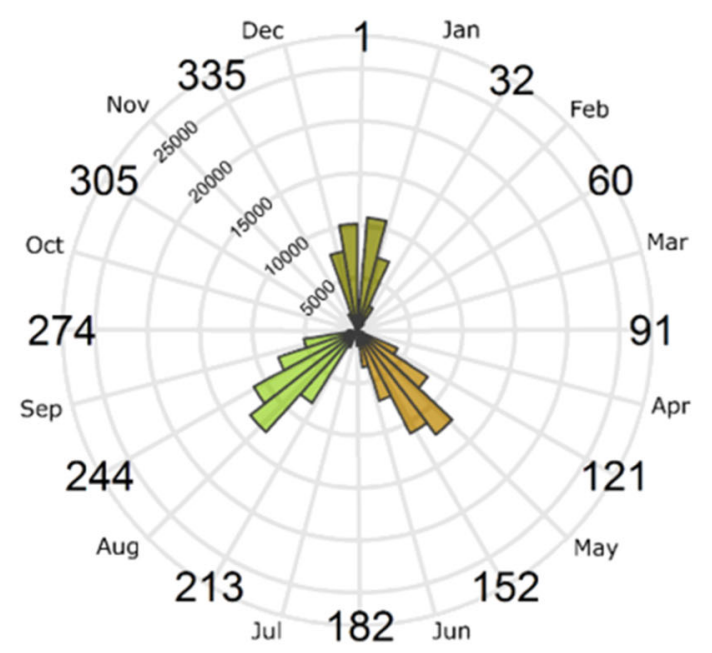

\section{Montane Vegetation}

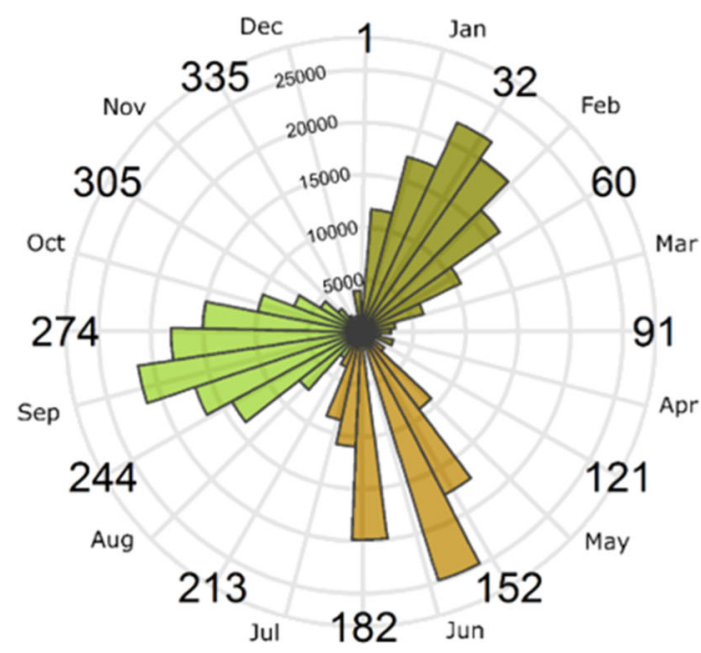

\section{Cerrado}

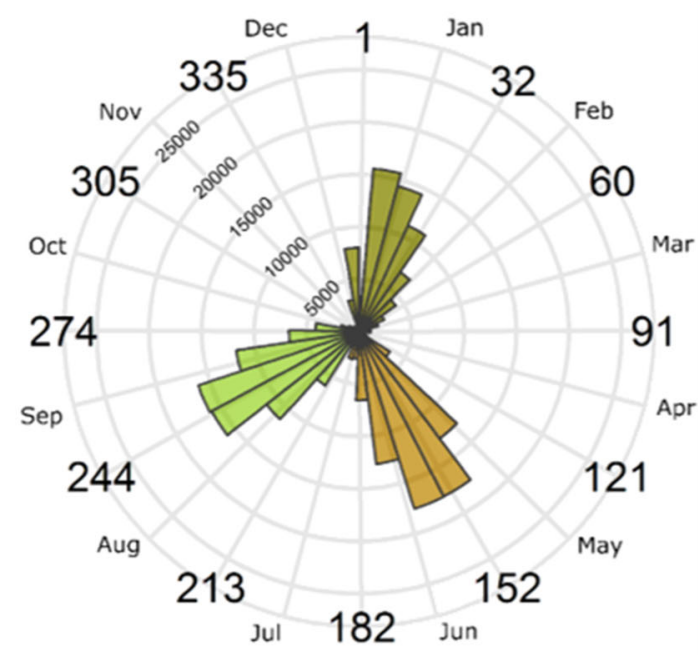

Moist Forests

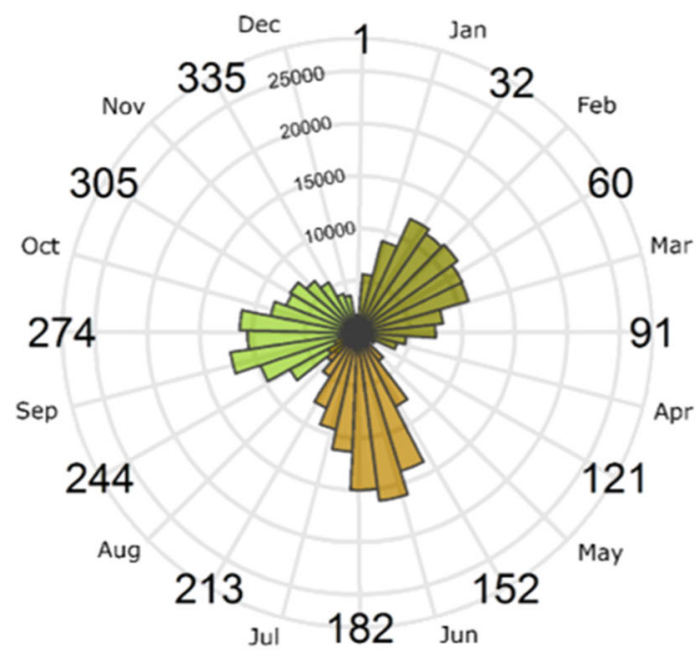

Start of the Season

Time of Mid-Season

End of the Season

Figure 4. Circular histograms of pixel frequencies for three phenological metrics derived from the average of the 14-year MODIS/NDVI time series, acquired from 25 samples of different vegetation types along the Espinhaço Mountain Range in south-eastern Brazil. Light green bars indicate the variation of the start of the growing season (SOS) dates; olive bars represent the time of the mid-season (MID) dates; and brown bars represent variation on end of the growing season (EOS) dates. Each bar corresponds to a bin width of 10 days, and bar length indicates the frequency (number of pixels) within each bin range.

We simulated the solar insolation budget using the Solar Radiation Tool of the ArcGIS Surface Analysis Toolset (Rich and others 1994). Insolation maps were obtained from an insolation model that accounts for clear-sky atmospheric conditions, elevation, surface orientation and occlusion from surrounding topography (Fu and Rich 2002). Our resulting variable was the total annual budget of incoming insolation (TII), corresponding to the sum of direct and diffuse radiation (Fu and Rich 2002). The atmospheric parameters of transmissivity and diffuse to direct radiation proportion 

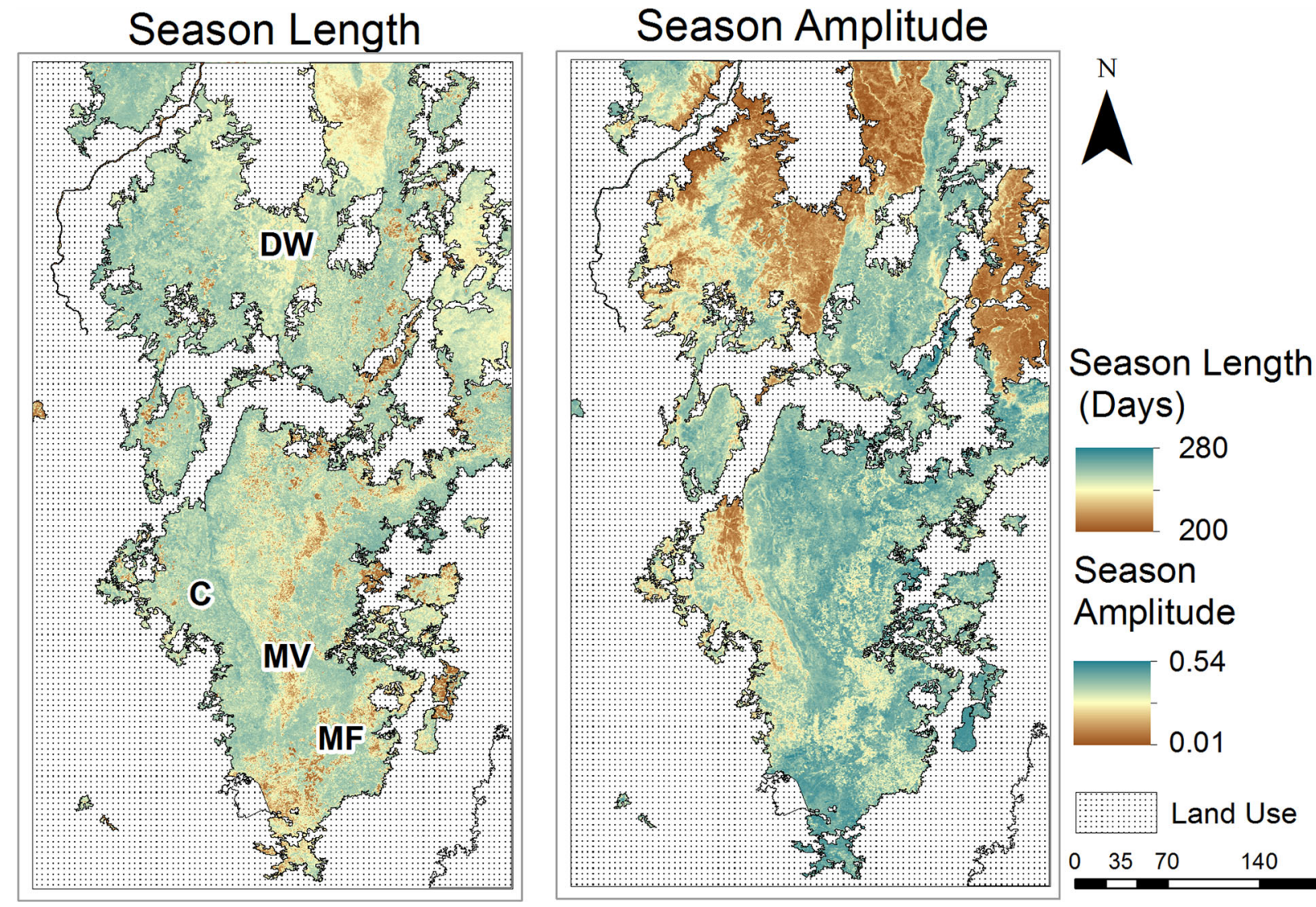

Season Amplitude
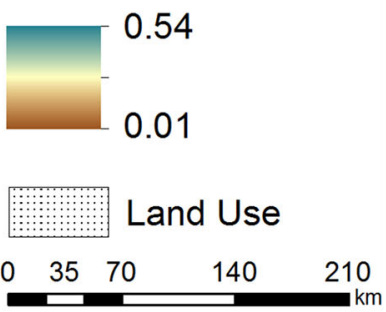

Figure 5. Mean length of the growing season (LOS) in number of days, and mean season amplitude (SA), unitless, estimated from a 14-year MODIS/NDVI time series of the Espinhaço Mountain Range, in south-eastern Brazil. DW dry woodlands, $C$ cerrado, $M V$ montane vegetation, $M F$ moist forest.

were set as 0.4 and 0.6 , respectively. Sky size was set to 200 cells, and we used the standard overcast sky diffuse model type (Fu and Rich 2002).

Because the algorithm calculates the radiation budget under continuous clear-sky conditions, we also derived a cloud cover frequency map using the quality assessment (QA) flags indicating cloud occurrence from the Terra MODIS MOD09GA daily surface reflectance product, at $1 \mathrm{~km}$ spatial resolution. Cloud cover was expressed as the percentage of observed cloudy days for the entire period between 01 January 2001 and 31 December 2015. Data processing was done using the Google Earth Engine cloud computing platform, using a custom JavaScript script that interfaces with the Engine API (https://developers.google.com/earth-engine/ playground).

\section{Data Extraction and Analysis}

Five broad vegetation classes, chosen based on their relevance and abundance across our study region, were delineated to aid the characterization of phenological patterns (Figure 1). We classified each vegetation type based on elevation (SRTM), and the mean and variance of each pixel in the entire MODIS/NDVI series. Class interpretation was complemented by Google Earth imagery, the official vegetation map of Brazil (IBGE 2002), and a land use map produced by the SIMBRASIL/ Otimizagro Project for 2013 (http://csr.ufmg.br/ simbrasil). The following classes were mapped:

- Moist forests: areas covered by tall trees, including gallery forests and cloud forests. This vegetation type is composed mostly by evergreen plants or partially by plants that lose part of their foliage for a very short period, when old leaves are shed and new foliage growth starts (Morellato and others 2000; de Lima and others 2015).

- Dry woodlands: an ecotonal zone of forests or woodlands dominated by sparse trees, the majority losing their foliage at the end of the growing season (Borchert and others 2002; Lima and Rodal 2010; Portillo-Quintero and Sánchez-Azofeifa 2010). 
- Montane vegetation: a heterogeneous mosaic of vegetation known in Brazil as campo rupestre sensu lato, occurring over elevations above $800 \mathrm{~m}$ and comprising mainly non-forest vegetation types dominated by rocky and sandy grasslands surrounding vegetation growing on rock outcrops (Fernandes 2016; Silveira and others 2016).

- Cerrado: a vegetation dominated by woody and shrubby neotropical savannas, also including a vegetation gradient spanning from C4 grasslands to closed canopy seasonal forests (Simon and others 2009).

- Land uses: agriculture, pasture, Eucalyptus plantations, urban areas and other land uses that are not natural vegetation.

We characterized the general spatial patterns of land surface phenology along the Espinhaço Range by averaging the per-pixel value of each phenological metric across the 14 growing seasons of the time series. All images were resampled to the MODIS spatial resolution $(250 \mathrm{~m})$, and phenological metrics and environmental variables were stacked in a multilayer image. We then sampled the stack to retrieve only pure pixels from each vegetation class, to avoid the inclusion of signals from mixed vegetation and from human-modified surfaces. Pure vegetation samples (polygons containing pixels with unmixed vegetation cover for each class) were manually delineated using visual interpretation of high-resolution Google Earth $^{\text {TM }}$ and Bing Maps ${ }^{\mathrm{TM}}$ imagery, using the OpenLayers plug-in of QGIS 2.14 software (www.qgis.org). We took 25 samples for each vegetation class, comprising a total of 26,122 pixels (dry woodlands $=4945$ pixels; $\quad$ cerrado $=6611$ pixels; montane vegetation $=7512$ pixels; moist forests $=7054$ pixels). We also cross-checked our sample classification with the TreeCO bibliographical database for forest descriptions (http://labtrop. ib.usp.br/doku.php?id=projetos:treeco:start) (de Lima and others 2015), to ensure they correctly represented each of the described vegetation types.

Using the pure vegetation samples extracted, we then fitted several general linear models using each phenology metric as the dependent variable $(Y)$,
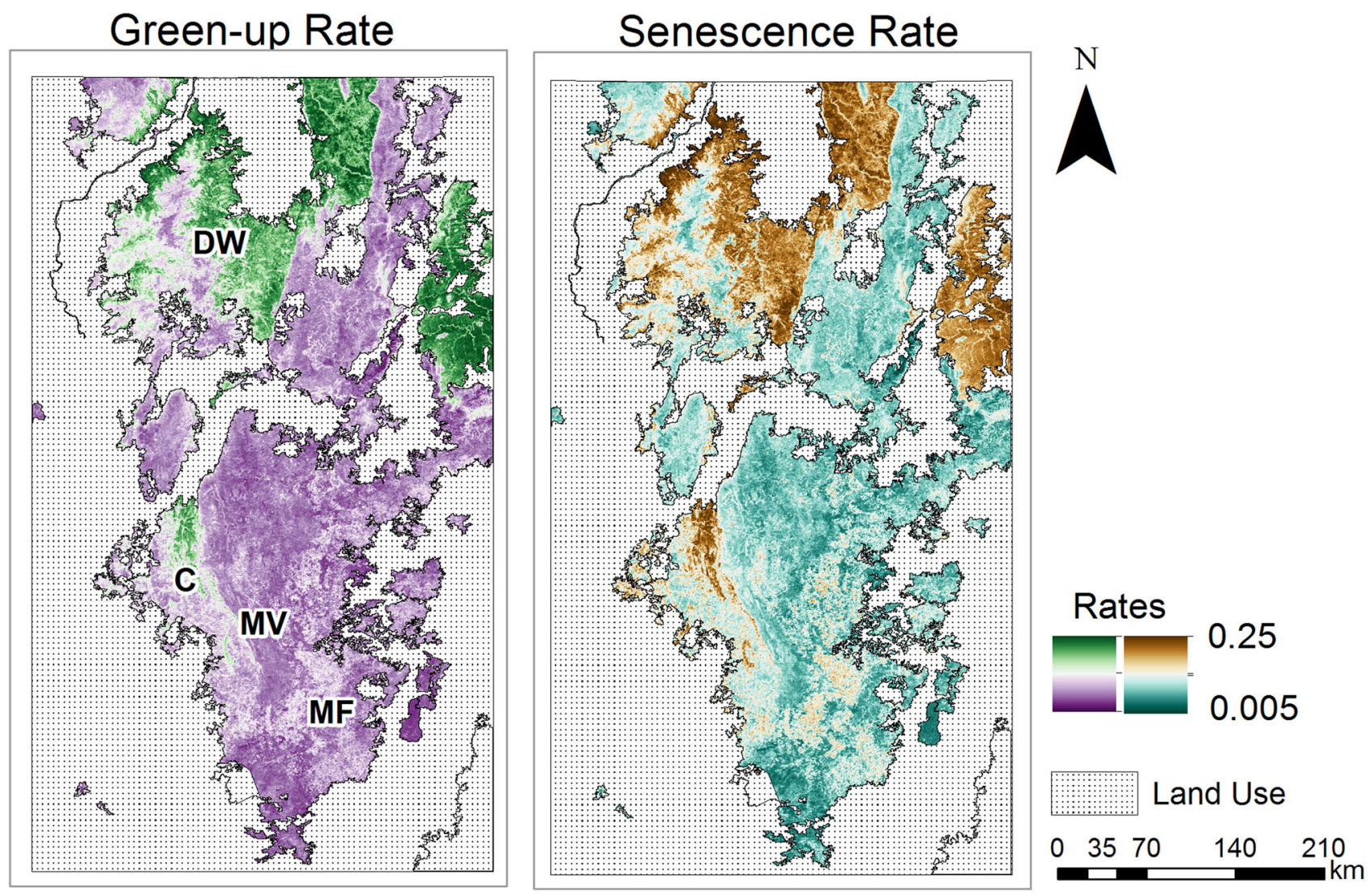

Figure 6. Mean rates of green-up and senescence for a 14-year MODIS/NDVI time across the Espinhaço Mountain Range in south-eastern Brazil. $D W$ dry woodlands, $C$ cerrado, $M V$ montane vegetation, $M F$ moist forest. 

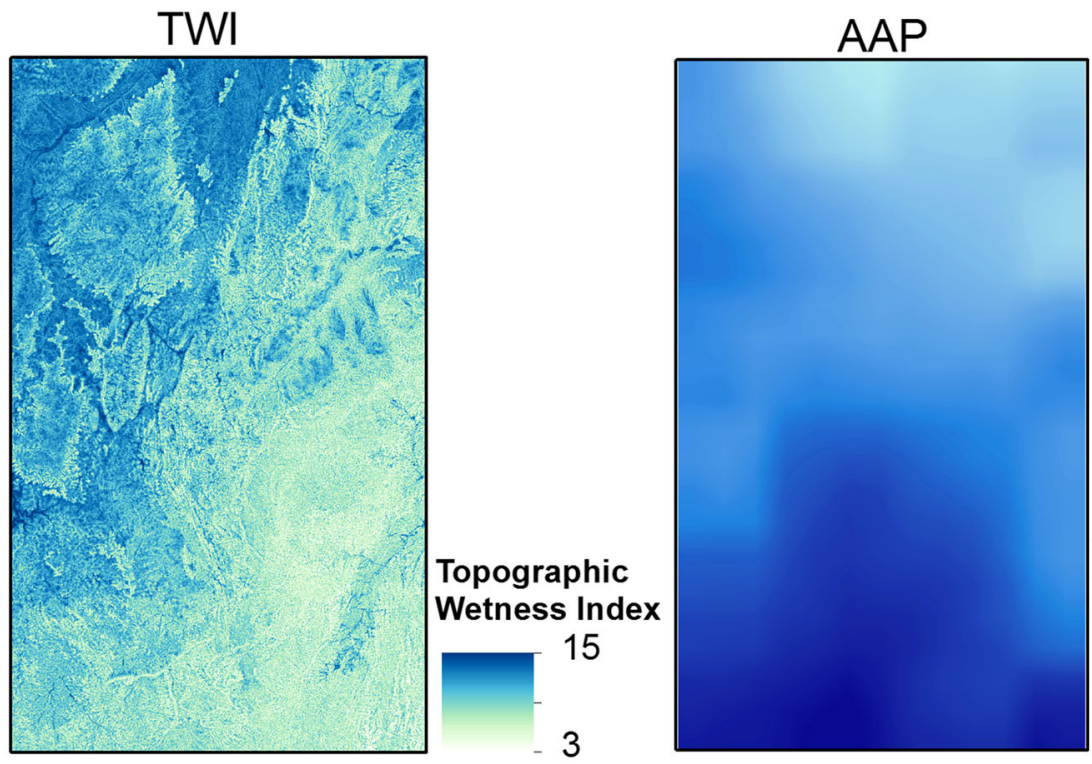

Annual Average

Precipitation (mm/year)

TA

TII

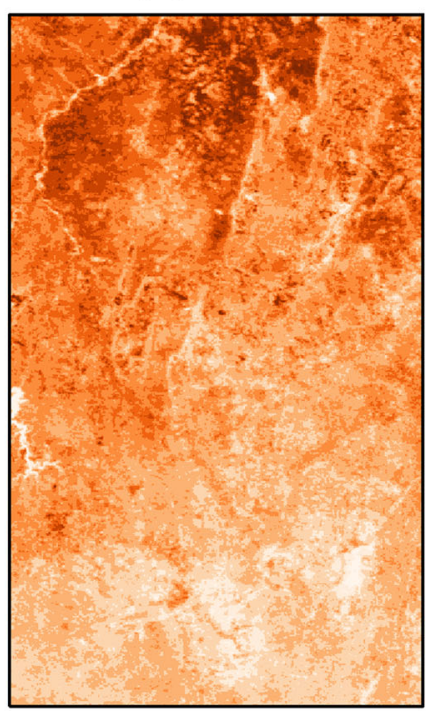

Temperature Amplitude $\left({ }^{\circ} \mathrm{C}\right)$

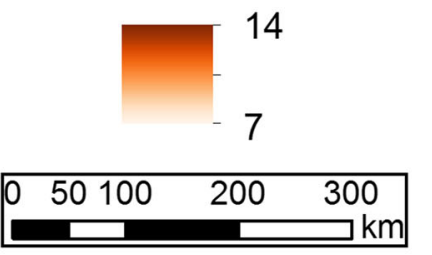

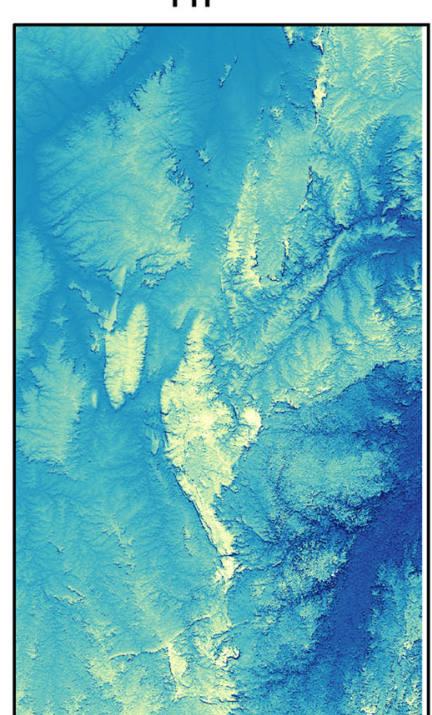

Total Incoming Insolation

$\left(\mathrm{kwh} / \mathrm{m}^{2}\right)$

2869

103

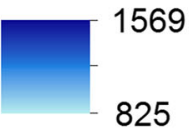

825

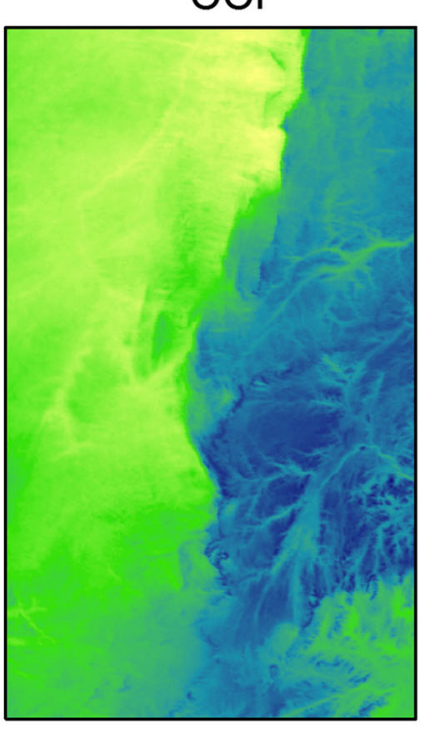

Cloud Cover Frequency \%

0.86

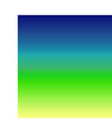

0.31

Figure 7. Distribution of environmental drivers across the Espinhaço Mountain Range, in south-eastern Brazil. TWI is the topographic wetness index (TWI, unitless), representing soil water accumulation capability-higher values indicate higher potential soil moisture. AAP represents the average annual of precipitation from 1998 to 2015, obtained from TRMM. TA is the temperature amplitude, derived from a MODIS time series (MOD11A2 product) spanning 2001-2015, and is the difference between the 90th percentile of day temperatures and the 10th percentile of night temperatures for the entire series. TII is the total incoming insolation from all sky directions, modelled based on topography in ArcGIS 10.3. CCF is the cloud cover frequency, obtained from MODIS data, during the period from 2013 to 2015. 
and different combinations of environmental drivers as predictors $(X)$, each model formulation representing different competing hypothesis on the expected relationship between phenology and environment. The models were fitted for all samples (global model), and then separately for each vegetation type (specific models). For each phenology metric, we specified two full models, representing our main environmental hypotheses, the first one using all single variables as independent explanatory terms, and the second including interaction terms between TWI and rainfall and between solar radiation and cloud cover frequency:

$$
\begin{aligned}
Y= & \beta_{0}+\beta_{1}(\mathrm{TII})+\beta_{2}(\mathrm{CCF})+\beta_{3}(\mathrm{TA})+\beta_{4}(\mathrm{AAP}) \\
& +\beta_{5}(\mathrm{TWI})+\varepsilon_{i} \\
Y= & \beta_{0}+\beta_{1}(\mathrm{TII})+\beta_{2}(\mathrm{CCF})+\beta_{3}(\mathrm{TII} * \mathrm{CCF})+\beta_{4}(\mathrm{TA}) \\
& +\beta_{5}(\mathrm{AAP})+\beta_{6}(\mathrm{TWI})+\beta_{7}(\mathrm{AAP} * \mathrm{TWI})+\varepsilon_{i}
\end{aligned}
$$

where $Y$ is the phenological metric, TII is the total incoming insolation $\left(\mathrm{Wh} \mathrm{m}^{-2}\right), \mathrm{CCF}$ is the cloud cover frequency $(\%)$, TA is the thermal amplitude $\left({ }^{\circ} \mathrm{C}\right)$, AAP is the average annual precipitation $\left(\mathrm{mm} \mathrm{year}^{-1}\right)$, TWI is the topographic wetness index (unitless), and $\varepsilon_{i}$ is the error term.

The term combining AAP and TWI describes the interaction between the amount of water (precipitation) entering the system and the soil capacity for water accumulation, which therefore determines potential water availability. The combination between annual insolation and cloud cover frequency (TII $* \mathrm{CCF}$ ) was used to describe how clouds can alter the balance between direct and diffuse radiation, as well as the total incoming PAR, therefore representing potential light availability. From the two global models, we assessed the contribution and significance of each environmental variable, using standardized model coefficients, and manually derived competing nested parsimonious models using Akaike's information criterion (AIC) as a model selection method (Burnham and Anderson 2004). We assessed multicollinearity among covariates by calculating the variance inflation factor (VIF) for each model predictor, and no evidence for collinearity was found. The highest VIF value was found for the TWI variable (VIF $=2.69$; for the models relating SA, GR and SR), still below the recommended threshold of 3 (Zuur and others 2010). All models were also checked for normality and independence of the residuals, with no issues found for any model.

\section{Results \\ Land Surface Phenology Patterns}

The spatial distribution of the 14-year averages for all phenological metrics revealed a well-defined geographic pattern for vegetation phenology along the meridional Espinhaço Range (Figures 2, 5, 6), following both latitudinal and elevational gradients. The maps show how phenology tracks the topography of the region, emphasizing the distinctive phenological patterns of higher-elevation vegetation.

The start of the growing season (SOS) happened earlier at lower elevations and in the western portions of the study area and was only later followed by the highest elevations and eastern portions of the Espinhaço Range. Timing for the midseason (MID) and end of season (EOS) dates tracked SOS, indicating that season displacement was more important than season length in separating each vegetation (Figures 3,4). Dry woodlands started their growing season first, by late August (doy $238 \pm 14 \mathrm{~d}, \pm 1 \mathrm{sd}$ ), followed by cerrado in the beginning of September (doy $250 \pm 21 \mathrm{~d}$ ) and montane vegetation by late September (doy $267 \pm 27 \mathrm{~d}$ ), while moist forests had the latest start dates, in early October (doy $284 \pm 34$ d) (Figures 3, 4). MID dates were consistently reached 140-145 days after the SOS, occurring towards the end of January for dry woodlands and cerrado, and in mid-late February, for montane vegetation and moist forests (Figures 3, 4). Dry woodlands were the first to shed their leaves, at the end of May (doy $145 \pm 15 \mathrm{~d}$ ), followed by cerrado in the beginning of June (doy $159 \pm 18 \mathrm{~d}$ ), montane vegetation in late June (doy $170 \pm 20 \mathrm{~d}$ ) and moist forests at the beginning of July (doy $187 \pm 31 d$ ). Leaf senescence occurred during the dry season, approximately nine months after leaf flush, and the duration of the leaf-off period was between 2 and 3 months.

The mean length of the season (LOS) was larger than 250 days for almost the entire region, and season length was inversely proportional to elevation, decreasing 1.58 days per $100 \mathrm{~m}$ (Figure 5). Montane vegetation along the Espinhaço Range and higher-elevation moist forests in the Iron Quadrangle (above $900 \mathrm{~m}$ ) had the shortest LOS, averaging 266 days $( \pm 27 \mathrm{~d}$ and $\pm 34 \mathrm{~d}$, respectively). Moist forests at lower elevations had mean LOS similar to dry woodlands and cerrado, 273 days ( $\pm 16 \mathrm{~d}$ and $\pm 23 \mathrm{~d}$, respectively). We also observed distinct latitudinal and elevational patterns for season amplitude (SA), emphasizing the 
strong seasonality of dry woodlands in the northern portion of the Espinhaço Range $(\mathrm{SA}=0.39 \pm 0.08$, unitless) (Figure 5). Cerrado also had a marked seasonality $(0.19 \pm 0.09)$, more similar to montane vegetation and moist forests had the lowest variability of season amplitude $(0.14 \pm 0.04$ and $0.12 \pm 0.05$, respectively)

Mean green-up (GR) and senescence (SR) rates were similar for the entire area, having well-defined patterns of variation across the latitudinal and elevational gradients (Figure 6), with each vegetation type having comparable GR and SR rates. Dry woodlands at the northern Espinhaço Range had the fastest rates of growing ( $\mathrm{GR}=0.036 \pm 0.009$, unitless) and senescence $(\mathrm{GR}=0.031 \pm 0.009)$, followed by cerrado $(\mathrm{GR}=0.016 \pm 0.009$ and $\mathrm{SR}=0.016 \pm 0.01)$. Montane vegetation had slower rates $(\mathrm{GR}=0.011 \pm 0.004$ and $\mathrm{SR}=$ $0.012 \pm 0.007)$, and moist forests had the slowest rates $\quad(\mathrm{GR}=0.010 \pm 0.005$ and $\mathrm{SR}=0.009 \pm$ $0.007)$.

\section{Environmental Drivers}

The temperature gradient along the Espinhaço Range had a well-defined pattern, showing increasing temperatures from east to west and south to north and lower temperatures at higher elevations. Thermal amplitude varied approximately $7^{\circ} \mathrm{C}$ in average along the Espinhaço Range, with a latitudinal pattern of lower amplitudes from north to south (Figure 7). At the northern portion of the Espinhaço Range, higher temperatures were observed at lower elevations, but this relationship did not hold for the southern portion of the range, where temperatures were more homogenous. Average annual precipitation (AAP) had a marked latitudinal pattern: higher precipitation rates were found at the southern parts of the Espinhaço Range, decreasing towards the north-eastern areas (Figure 7), with precipitation ranging from 852 to $1569 \mathrm{~mm} \mathrm{y}^{-1}$. Rainfall patterns in the state of Minas Gerais are closely linked to the effects of the South Atlantic Convergence Zone (SACZ), which operates in a stationary way, especially in the $19^{\circ} \mathrm{S}$ and $20^{\circ} \mathrm{S}$ latitude, explaining the larger precipitation volume in these latitudes (Carvalho and others 2004). TWI had a gradient from east to west, with lower values at the eastern side of the Espinhaço Range due to the steeper terrain and small contributing drainage areas. Terrain-estimated insolation had higher values at the highest elevations, and several shaded areas occurred due to the Espinhaço rugged topography (Figure 7). Cloud cover frequency (CCF) had a strong pattern of variation from east to west, being more frequent in the eastern and northern regions of the Espinhaço Range, where moist forests and high-elevation grasslands can be found (Figure 7).

\section{Environmental Drivers of Land Surface Phenology}

Water and radiation variables were the best predictors of LSP across the Espinhaço Range, being always included in the most parsimonious models (Table S1-Supplementary Data). For season metrics (SOS, EOS and LOS), potential water availability and potential light availability (interaction terms) were the strongest predictors. We found strong influence of both potential light availability and potential water availability in SOS dates $\left(R^{2}=0.78, p<0.0001\right)$, whereas EOS dates were better explained by potential water availability and cloud cover frequency $\left(R^{2}=0.77, p<0\right.$. 0001). LOS was also strongly influenced by potential light availability and potential water availability $\left(R^{2}=0.67, p<0.0001\right)$. For phenological metrics related to productivity (GR, SR and SA), temperature amplitude also had a strong influence, being positively correlated and explaining a significant portion of variation for GR and SR $\left(R^{2}=0.77\right.$, $p<0.05$ and $R^{2}=0.76, p<0.0001$, respectively) as well as for SA $\left(R^{2}=0.77, p<0.0001\right)$.

Looking at the vegetation-specific models of phenological metrics, we observed the relative contribution of water-, light- and temperature-related drivers (Table S2-Supplementary Data). A combination of potential light availability, potential water availability and $T A$ influenced most of the phenological metrics described for cerrado, explaining more than $69 \%$ of variation, with the exception of SOS dates, which had $78 \%$ of variation explained only by potential light and water availability (Supplementary Table S2). Potential light availability and potential water availability also had a strong influence on montane vegetation phenology, explaining more than $68 \%$ of SOS, EOS and LOS dates, but less than $40 \%$ for GR, SR and SA. No evidence of TA influence was found for montane vegetation. Moist forests were also influenced by potential water availability and potential light availability, which explained more than 50\% of the variance found for SOS, EOS and LOS dates. The combination of potential water availability, potential light availability and $T A$ had a strong influence on GR, SR and SA, explaining more than $80 \%$ of the variance for moist forests. Dry forests were influenced by $T A$ for all phenological metrics assessed, except for LOS, where no significant 
relation was found. TA explained just about $20 \%$ of the variance on the SOS and EOS dates and about $28 \%$ for GR, SR and SA for dry woodlands.

\section{Discussion}

Although climate can be considered as the main abiotic factor controlling phenological dynamics, topography had a key role in modulating the environmental processes influencing LSP in the Espinhaço Range. In temperate mountains, topography is pointed out as a strong predictor of snowmelt, snow accumulation and temperature change across elevations, influencing leaf onset and leaf development (Hudson Dunn and de Beurs 2011; Hwang and others 2014). However, we show that in the absence of snow and/or freezing temperatures, complex topography still results in high variability of LSP patterns in the Espinhaço mountains, which appears to be a consequence of interactions between topography-mediated water and light availability, compounded by temperature amplitude. This complex topographic matrix and resulting topoclimatic variability allows the coexistence of highly diverse vegetation types (Fernandes 2016; Silveira and others 2016).

The importance of rainfall and its interaction with topography for LSP is shown by the consistent selection of potential water availability (interaction term between AAP and TWI) in the statistical models. In terrestrial plants, root water uptake is the most common water-acquisition mechanism (Oliveira and others 2016) and it has been used to explain species coexistence in the cerrado savannas (Rossatto and others 2014). Herbaceous plants, as found in cerrado and montane grasslands, with their dense and shallow root systems, tend to colonize shallow soils, where water is more superficial (Tannus and others 2006; Archibald and Scholes 2007; Rossatto and others 2014). Woody plants, on the other hand, are highly plastic with respect to preferential water uptake, varying from shallow to deep soil sources according to small changes in topography (Rossatto and others 2014). According to Rossatto and others (2014), competition for water between woody and herbaceous species is maximized at shallow slopes with deeper soils, while woody plants are outcompeted by herbaceous species along shallow soil conditions

Our results also highlight the importance of combined total incoming insolation and cloud cover (potential light availability) on plant phenology. Insolation is widely known to drive the timing of leaf phenology in the tropics (Wright and van Schaik 1994; Borchert and others 2005, 2015;
Mittelbach and others 2007; Calle and others 2010; Jones and others 2014; Bi and others 2015). Seasonal and spatial variations in cloud coverage can result in substantial seasonality in light availability to plants. Cloud cover had a strongly defined spatial pattern, due to the influence of the Atlantic tropical mass, forming an area of stationary nebulosity along the eastern faces and higher-elevational areas of the ER mountains (Coelho and others 2016). Clouds can reduce direct beam radiation and increase diffuse radiation, which penetrate canopies more efficiently and can increase whole canopy carbon uptake even when total irradiance is reduced (Graham and others 2003).

Our results also show that temperature has a less strong, but still fundamental role in determining vegetation dynamics in snow-free tropical mountains. Temperature has long been recognized as a fundamental constraint on many biological processes, which interacts with radiation and water to impose complex and varying limitations on vegetation activity (Myneni and others 2007; Calle and others 2010; Pau and others 2013; Borchert and others 2015). We found that temperature amplitude influenced the rates of plant development, that is, the speed of green-up and senescence, and also the strength of seasonality, across all vegetation types. According to Körner (2006), temperature does not necessarily control critical ontogenetic phase changes such as bud-break induction, flowering or leaf senescence, but the speed at which plants and their organs pass through developmental phases does depend on temperature. Furthermore, temperature is one of the key environmental factors driving evapotranspiration, thus contributing to water availability and plant-water relations.

Plant species can adapt and/or acclimatize to a variety of environmental conditions (Colwell and others 2008), often displaying different strategies, as we observed for LSP across the Espinhaço Range mountains. With the exception of moist forests, leaf flush occurred mostly before the start of the rainy season, indicating that vegetation types occurring across the Espinhaço Range are predominantly of the drought-tolerant type (Reich and Borchert 1984). This means that most plants are capable of storing or accessing water throughout the season, rehydrating after leaf shedding regardless of the length of the dry season (Borchet and others 2002). Because the timing of leaf flush requires predictable temporal cues in a limiting environment, it is possible that leaf flush is triggered by light-related environmental cues that precede the wet season, such as changes in irradiance (Borchert and others 
2005, 2015; Zimmerman and others 2007; Davies and others 2013; Jones and others 2014). We suggest that the timing of leaf flush for vegetation in the Espinhaço Range has evolved in response to seasonal variations in both irradiance and water availability, since total incoming radiation, cloud frequency and potential water availability were found to be the best predictors of leaf flush (start of the season). Our results (Figure 4) are consistent with previous findings showing that tropical tree phenology has evolved to produce new leaves coinciding with peaks in solar irradiance (Wright and van Schaik 1994; Myneni and others 2007; Jones and others 2014; Bi and others 2015; Borchert and others 2015). By flushing leaves before the wet season, plants may keep leaves for longer periods, having more opportunities for photosynthetic assimilation and growth (van Schaik and others 1993; Calle and others 2010; Jones and others 2014; Bi and others 2015) while minimizing damage by herbivory, which is more intense during the rainy season (Coley 1988). This strategy may also apply to several perennial grass species at the mountaintop of Espinhaço Range, but this has not been studied to date.

Leaf fall in seasonal forests has been directly or indirectly related to water stress and the occurrence of a more or less severe dry season (Reich and Borchert 1984). Because leaf fall had different timings for each vegetation type but always occurred during the dry season, vegetation types in the Espinhaço Range must have different strategies to deal with water shortage, and shedding their leaves may be a response to the first signs of water deficit (Reich and Borchert 1984; Morellato and others 2000; Lima and Rodal 2010). Our results are consistent with water deficit influencing leaf fall events, but residual variance in the models may be explained by endogenous processes rather than environmental cues. Lers (2007) states that leaf senescence is highly regulated by physiological processes promoting plant survival, growth and reproduction.

Season length is usually determined by the presence of snow in cold mountain environments (Inouye and Wielgolaski 2013), and no patterns and associated drivers have been reported for snow-free mountains. We propose that water and light availability act simultaneously to define the length of the growing season for the snow-free Espinhaço Mountain Range vegetation.

LSP patterns of green-up and senescence rates, as well as season amplitude are connected with the dominance of phenological functional types of each vegetation. Usually, the mix of evergreen and deciduous species gives tropical dry forests a phenological complexity that is not found in other tropical forest formations (Reich and Borchert 1984; Portillo-Quintero and Sánchez-Azofeifa 2010). The faster green-up and senescence rates of dry woodlands observed in this study are explained by the predominance of strongly seasonal, deciduous species in this vegetation (Pezzini and others 2014). Moist forest vegetation, on the other hand, encompasses semideciduous and cloud forests that are dominated by a different proportion of deciduous, semideciduous and evergreen species (Lopes and others 2012). Semideciduous forests may have up to $50 \%$ of deciduous to semideciduous trees (Morellato and others 1989, 2013; Morellato and Leitão-Filho 1992), maintaining reduced leaf cover during the dry season and increasing coverage during the wet season, with short deciduous stages (Singh and Kushwaha 2005). On cloud forests, however, leaf flush and leaf fall may be observed year-round (Morellato and others 2000), and leaf cover is not reduced, leading to slower green-up and senescence rates and lower seasonality.

\section{Concluding Remarks}

Our study unravels land surface phenology patterns along elevational and latitudinal gradients, highlighting the distinctive phenology of higherelevational tropical vegetation and describes for the first time the large-scale patterns of growing season length in seasonally dry neotropical vegetation. Although we did not find evidence of temperaturerelated periodicity, such as observed for temperate mountain vegetation, we did observe effects of temperature amplitude over the rates of green-up and senescence events, indicating that tropical seasonally dry vegetation could be sensitive to the increases in global temperatures. That is especially true for dry woodlands and cerrado vegetation, which had a more pronounced seasonality and were more susceptible to the effects of temperature.

We demonstrated that different vegetation types have diverse leaf phenology strategies in seasonally dry tropical environments and seem to maximize the use of water and light, whose availability is strongly influenced by topography. Our spatially explicit analysis of the processes driving phenological patterns in a snow-free tropical mountain shows the importance of environmental factors acting simultaneously as proximate cues for tropical plant phenology, from the highest elevations at different latitudes, to the "less seasonal" lower-elevation moist forests, as has been broadly shown for the lowland tropics (Morellato and others 2000). 
Our results highlight the need for further and combined ecological studies from local to regional scales, to disentangle the relative importance of direct and indirect effects of water, light, temperature and especially cloud cover seasonality on tropical land surface phenology dynamics.

\section{ACKNOWLEDGEMENTS}

The authors thank Lars Elkhund and Per Jönsson for the invaluable help running TIMESAT and Dr. Jeffrey Hicke and the two anonymous reviewers for comments that improved the quality of this article. Our research was supported by the grant \#2013/ 50155-0, São Paulo Research Foundation (FAPESP) and Microsoft Research Institute, and AS Streher receives a FAPESP scholarship (Grant \#2015/ 17534-3 and BEPE Grant \#2016/00757-2). LPCM and TSFS receive research productivity grants from CNPq (\#310761/2014-0 and \#310144/2015-9). We are very thankful to our colleagues from the Ecosystem Dynamics Observatory (EcoDyn) and the Phenology Lab for the helpful insights and discussions.

\section{REFERENCES}

Archibald S, Scholes RJ. 2007. Leaf green-up in a semi-arid African savanna -separating tree and grass responses to environmental cues. J Veg Sci 18:583-94.

Beven KJ, Kirbk MJ. 1979. A physically based, variable contributing area model of basin hydrology. Hydrol Sci Bull 24:43-69.

Bi J, Knyazikhin Y, Choi S, Park T, Barichivich J, Ciais P, Fu R, Ganguly S, Hall F, Hilker T, Huete A, Jones M, Kimball J, Lyapustin AI, Mõttus M, Nemani RR, Piao S, Poulter B, Saleska SR, Saatchi SS, Xu L, Zhou L, Myneni RB. 2015. Sunlight mediated seasonality in canopy structure and photosynthetic activity of Amazonian rainforests. Environ Res Lett 10:64014.

Borchert R, Calle Z, Strahler AH, Baertschi A, Magill RE, Broadhead JS, Kamau J, Njoroge J, Muthuri C. 2015. Insolation and photoperiodic control of tree development near the equator. New Phytol 205:7-13.

Borchert R, Renner SS, Calle Z, Navarrete D, Tye A, Gautier L, Spichiger R, von Hildebrand P. 2005. Photoperiodic induction of synchronous flowering near the Equator. Nature 433:6279.

Borchert R, Rivera G, Hagnauer W. 2002. Modification of Vegetative Phenology in a Tropical Semi-deciduous Forest by Abnormal Drought and Rain l. Biotropica 34:27-39.

Borchet R, Rivera G, Hagnauer W. 2002. Modification of Vegetative Phenology in a Tropical Semi-deciduous Forest by Abnormal Drought and Rain. Biotropica 4:27-39.

Briggs JM, Knapp AK. 1995. Interannual variability in primary production in tallgrass prairie: climate, soil moisture, topographic position, and fire as determinants of aboveground biomass. Am J Bot 82:1024-30.
Burnham KP, Anderson DR. 2004. Model Selection and Multimodel Inference. (Burnham KP, Anderson DR, editors.). New York, NY: Springer New York

Calle Z, Schlumpberger BO, Piedrahita L, Leftin A, Hammer SA, Tye A, Borchert R. 2010. Seasonal variation in daily insolation induces synchronous bud break and flowering in the tropics. Trees - Struct Funct 24:865-77.

Carvalho LMV, Jones C, Liebmann B. 2004. The South Atlantic Convergence Zone: intensity, form, persistence, and relationships with intraseasonal to interannual activity and extreme rainfall. J Clim 17:88-108.

Chambers LE, Altwegg R, Barbraud C, Barnard P, Beaumont LJ, Crawford RJM, Durant JM, Hughes L, Keatley MR, Low M, Morellato PC, Poloczanska ES, Ruoppolo V, Vanstreels RET, Woehler EJ, Wolfaardt AC. 2013. Phenological Changes in the Southern Hemisphere. HÃ@rault B, editor. PLoS One 8:e75514.

Cleland EE, Chuine I, Menzel A, Mooney HA, Schwarz M. 2007. Shifting plant phenology in response to global change. Trends Ecol Evol 22:357-65.

Coelho MS, Fernandes GW, Pacheco P, Diniz V, Meireles A, Santos RM dos, Carvalho FA, Negreiros D. 2016. Archipelago of Montane Forests Surrounded by Rupestrian Grasslands: New Insights and Perspectives. In: Fernandes GW, editor. Ecology and conservation of mountain top grasslands in Brazil. Springer International Publishing. pp 129-56.

Coley PD. 1988. Effects of plant growth rate and leaf lifetime on the amount and type of anti-herbivore defense. Oecologia 74:531-6.

Colwell RK, Brehm G, Cardelus CL, Gilman AC, Longino JT. 2008. Global warming, elevational range Shifts, and lowland biotic attrition in the wet tropics. Science (80) 322:258-61.

Davies TJ, Wolkovich EM, Kraft NJB, Salamin N, Allen JM, Ault TR, Betancourt JL, Bolmgren K, Cleland EE, Cook BI, Crimmins TM, Mazer SJ, Mccabe GJ, Pau S, Regetz J, Schwartz MD, Travers SE. 2013. Phylogenetic conservatism in plant phenology. J Ecol 101:1520-30.

de Beurs KM, Henebry GM. 2004. Land surface phenology, climatic variation, and institutional change: Analyzing agricultural land cover change in Kazakhstan. Remote Sens Environ 89:497-509.

de Lima RAF, Mori DP, Pitta G, Melito MO, Bello C, Magnago LF, Zwiener VP, Saraiva DD, Marques MCM, de Oliveira AA, Prado PI. 2015. How much do we know about the endangered Atlantic Forest? Reviewing nearly 70 years of information on tree community surveys. Biodivers Conserv 24:2135-48.

Fernandes GW. 2016. Ecology and conservation of mountaintop grasslands in Brazil. 1. (Fernandes GW, editor.). Cham: Springer International Publishing.

Fu P, Rich PM. 2002. A geometric solar radiation model with applications in agriculture and forestry. Comput Electron Agric 37:25-35.

Galvão LS, Breunig FM, Teles TS, Gaida W, Balbinot R. 2016. Investigation of terrain illumination effects on vegetation indices and VI-derived phenological metrics in subtropical deciduous forests. GIScience Remote Sens 53:360-81.

Giulietti AM, Pirani JR. 1988. Patterns of geographic distribution of some plant species from the Espinhaço Range, Minas Gerais and Bahia, Brazil. In: Vanzolini PE, Heyer WR, editors. Proceedings of a workshop on Neotropical Distribution Patterns. Academia Brasileira de Ciências, Rio de Janeiro. pp 39-69. 
Gotelli NJ, Graves G. 1996. The temporal niche. Null Models in Ecology. Washington, District of Columbia: Smithsonian Institution Press. p 95-111.

Graham EA, Mulkey SS, Kitajima K, Phillips NG, Wright SJ. 2003. Cloud cover limits net CO2 uptake and growth of a rainforest tree during tropical rainy seasons. Proc Natl Acad Sci 100:572-6.

Guan K, Pan M, Li H, Wolf A, Wu J, Medvigy D, Caylor KK, Sheffield J, Wood EF, Malhi Y, Liang M, Kimball JS, Saleska SR, Berry J, Joiner J, Lyapustin AI. 2015. Photosynthetic seasonality of global tropical forests constrained by hydroclimate. Nat Geosci 8:284-9.

Henebry GM, de Beurs KM. 2013. Remote Sensing of Land Surface Phenology: A Prospectus. In: Schwartz MD, editor. Phenology: An Integrative Environmental Science. Dordrecht: Springer Netherlands. pp 385-411.

Hudson Dunn A, de Beurs KM. 2011. Land surface phenology of North American mountain environments using moderate resolution imaging spectroradiometer data. Remote Sens Environ 115:1220-33.

Huete A, Justice C, Van Leeuwen WJD. 1999. Modis Vegetation Index, Algorithm Theoretical Basis Document.

Hwang T, Band LE, Miniat CF, Song C, Bolstad PV, Vose JM, Love JP. 2014. Divergent phenological response to hydroclimate variability in forested mountain watersheds. Glob Chang Biol 20:2580-95.

Inouye DW, Wielgolaski FE. 2013. Phenology at high altitudes. In: Schwartz MD, editor. Phenology: An Integrative Environmental Science. Dordrecht: Springer Netherlands. pp 24972 .

Jolly WM, Nemani R, Running SW. 2005. A generalized, bioclimatic index to predict foliar phenology in response to climate. Glob Chang Biol 11:619-32.

Jones MO, Kimball JS, Nemani RR. 2014. Asynchronous Amazon forest canopy phenology indicates adaptation to both water and light availability. Environ Res Lett 9:124021

Jonsson P, Eklundh L. 2002. Seasonality extraction by function fitting to time-series of satellite sensor data. IEEE Trans Geosci Remote Sens 40:1824-32.

Jönsson P, Eklundh L. 2004. TIMESAT—a program for analyzing time-series of satellite sensor data. Comput Geosci 30:833-45.

Klisch A, Atzberger C. 2016. Operational drought monitoring in Kenya using MODIS NDVI time series. Remote Sens 8:267.

Knapp AK, Seastedt TR. 1986. Detritus accumulation limits productivity of tallgrass prairie. Bioscience 36:662-8.

Körner C. 2006. Significance of temperature in plant life. In: James I.L. Morison, Michael D. Morecroft, editors. Plant Growth and Climate Change. Oxford, UK: Blackwell Publishing Ltd. pp 48-69.

Krishnaswamy J, John R, Joseph S. 2014. Consistent response of vegetation dynamics to recent climate change in tropical mountain regions. Glob Chang Biol 20:203-15.

Lers A. 2007. Environmental regulation of leaf senescence. In: Gan Susheng, Ed. Senescence Processes in Plants. Oxford: Blackwell Publishing Ltd. p 108-44.

Lima ALA, Rodal MJN. 2010. Phenology and wood density of plants growing in the semi-arid region of northeastern Brazil. J Arid Environ 74:1363-73.

Lopes SDF, Schiavini I, Oliveira AP, Vale VS. 2012. An ecological comparison of floristic composition in seasonal semideciduous forest in southeast Brazil: implications for conservation. Int $\mathrm{J}$ For Res 2012:1-14.
Mittelbach GG, Schemske DW, Cornell HV, Allen AP, Brown JM, Bush MB, Harrison SP, Hurlbert AH, Knowlton N, Lessios HA, McCain CM, McCune AR, McDade LA, McPeek MA, Near TJ, Price TD, Ricklefs RE, Roy K, Sax DF, Schluter D, Sobel JM, Turelli M. 2007. Evolution and the latitudinal diversity gradient: speciation, extinction and biogeography. Ecol Lett 10:315-31.

Morellato LPC, Alberton B, Alvarado ST, Borges B, Buisson E, Camargo MGG, Cancian LF, Carstensen DW, Escobar DFE, Leite PTP, Mendoza I, Rocha NMWB, Soares NC, Silva TSF, Staggemeier VG, Streher AS, Vargas BC, Peres CA. 2016. Linking plant phenology to conservation biology. Biol Conserv 195:60-72.

Morellato LPC, Camargo MGG, Gressler E. 2013. A review of plant phenology in South and Central America. In: Schwartz MD, editor. Phenology: An Integrative Environmental Science. Dordrecht: Springer Netherlands. pp 91-113.

Morellato LPC, Leitão-Filho HF. 1992. Padrões de frutificação e dispersão na Serra do Japi. In: Morellato LPC, Ed. Historia natural da Serra do Japi: ecologia e preservacao de uma area florestal no Sudeste do Brasil. Editora da Unicamp/Fapesp: Campinas. p 112-40.

Morellato LPC, Rodrigues R, Leitão-Filho H, Joly CA. 1989. Estudo comparativo da fenologia de espécies arbóreas de floresta de altitude e floresta mesófila semidecídua na Serra do Japi, Jundiaí, São Paulo. Rev Bras Bot 12:85-98.

Morellato LPC, Talora DC, Takahasi A, Bencke CC, Romera EC, Zipparro VB. 2000. Phenology of Atlantic rain forest trees: A comparative study. Biotropica 32:811-23.

Myneni RB, Yang W, Nemani RR, Huete AR, Dickinson RE, Knyazikhin Y, Didan K, Fu R, Negron Juarez RI, Saatchi SS, Hashimoto H, Ichii K, Shabanov NV, Tan B, Ratana P, Privette JL, Morisette JT, Vermote EF, Roy DP, Wolfe RE, Friedl MA, Running SW, Votava P, El-Saleous N, Devadiga S, Su Y, Salomonson VV. 2007. Large seasonal swings in leaf area of Amazon rainforests. Proc Natl Acad Sci 104:4820-3.

Nippert JB, Knapp AK, Briggs JM. 2006. Intra-annual rainfall variability and grassland productivity: can the past predict the future? Plant Ecol 184:65-74

Oliveira RS, Abrahão A, Pereira C, Teodoro GS, Mauro Brum S, Alcantara U, Lambers H. 2016. Ecophysiology of Campos Rupestres Plants. In: Fernandes GW, editor. Ecology and conservation of mountain top grasslands in Brazil. Springer International Publishing. pp 228-62.

Pau S, Wolkovich EM, Cook BI, Nytch CJ, Regetz J, Zimmerman JK, Joseph Wright S. 2013. Clouds and temperature drive dynamic changes in tropical flower production. Nat Clim Chang 3:838-42.

Peñuelas J, Rutishauser T, Filella I. 2009. Phenology feedbacks on climate change. Science 324:887-8.

Pezzini FF, Ranieri BD, Brandão DO, Fernandes GW, Quesada M, Espírito-Santo MM, Jacobi CM. 2014. Changes in tree phenology along natural regeneration in a seasonally dry tropical forest. Plant Biosyst - An Int J Deal with all Asp Plant Biol 148:965-74.

Polgar CA, Primack RB. 2011. Leaf-out phenology of temperate woody plants: from trees to ecosystems. New Phytol 191:92641.

Portillo-Quintero CA, Sánchez-Azofeifa GA. 2010. Extent and conservation of tropical dry forests in the Americas. Biol Conserv 143:144-55.

Reed BC, Schwartz MD, Xiao X. 2009. Remote Sensing Phenology. In: Noormets A, editor. Phenology of Ecosystem 
Processes: Applications in Global Change Research. New York, NY: Springer New York. pp 231-46.

Reich PB, Borchert R. 1984. Water Stress and Tree Phenology in a Tropical Dry Forest in the Lowlands of Costa Rica. J Ecol 72:61.

Reich PB, Peterson DW, Wedin DA, Wrage K. 2001. Fire and vegetation effects on productivity and nitorgen cycling across a forest-grassland continuum. Ecology 82:1703-19.

Rich PM, Dubayah R, Hetrick WA, Saving SC. 1994. Using viewshed models to calculate intercepted solar radiation: applications in ecology. Am Soc Photogramm Remote Sens Tech Pap 524-9.

Richardson AD, Bailey AS, Denny EG, Martin CW, O'Keefe J. 2006. Phenology of a northern hardwood forest canopy. Glob Chang Biol 12:1174-88.

Rivera G, Elliott S, Caldas LS, Nicolossi G, Coradin VTR, Borchert R. 2002. Increasing day-length induces spring flushing of tropical dry forest trees in the absence of rain. Trees 16:44556.

Rocha NMWB, Carstensen DW, Wilson Fernandes G, Le Stradic S, Buisson E, Morellato LPC. 2016. Phenology patterns across a rupestrian grassland altitudinal gradient. In: Fernandes GW, editor. Ecology and conservation of mountain top grasslands in Brazil. Springer International Publishing. pp 275-90.

Rossatto DR, Silva LCR, Sternberg LSL, Franco AC. 2014. Do woody and herbaceous species compete for soil water across topographic gradients? Evidence for niche partitioning in a Neotropical savanna. South African J Bot 91:14-18.

Schaefer CEGR, Corrêa GR, Candido HG, Arruda DM, Nunes JA, Araujo RW, Rodrigues PMS, Filho EIF, Pereira AFS, Brandão PC, NeriCarlos A V. 2016. The physical environment of Rupestrian Grasslands (Campos Rupestres) in Brazil: geological, geomorphological and pedological characteristics, and interplays. In: Fernandes GW, editor. Ecology and conservation of mountain top grasslands in Brazil. Springer International Publishing. pp 15-53.

Schimel DS, Kittel TGF, Knapp AK, Seastedt TR, Knapp AK, Seastedt TR, Parton WJ, Brown VB. 1991. Physiological interactions along resource gradients in a tallgrass prairie. Ecology 72:672-84.

Silveira FAO, Negreiros D, Barbosa NPU, Buisson E, Carmo FF, Carstensen DW, Conceição A A., Cornelissen TG, Echternacht L, Fernandes GW, Garcia QS, Guerra TJ, Jacobi CM, LemosFilho JP, Le Stradic S, Morellato LPC, Neves FS, Oliveira RS, Schaefer CE, Viana PL, Lambers H. 2016. Ecology and evolution of plant diversity in the endangered campo rupestre: a neglected conservation priority. Plant Soil 403:129-52.
Simon MF, Grether R, de Queiroz LP, Skema C, Pennington RT, Hughes CE. 2009. Recent assembly of the Cerrado, a neotropical plant diversity hotspot, by in situ evolution of adaptations to fire. Proc Natl Acad Sci 106:20359-64.

Singh KP, Kushwaha CP. 2005. Emerging paradigms of tree phenology in dry tropics. Curr Sci 89:964-75.

Sobreiro JFF, Silva TSF, Streher AS. 2015. Avaliação multi-escala do regime de precipitação da Cadeia do Espinhaço Meridional (Brasil). In: XVII Congresso de Iniciação Científica da Unesp. Rio Claro.

Tannus JLS, Assis MA, Morellato LPC. 2006. Fenologia reprodutiva em campo sujo e campo úmido numa área de Cerrado no sudeste do Brasil, Itirapina - SP. Biota Neotrop 6.

Teles TS, Galvão LS, Breunig FM, Balbinot R, Gaida W. 2015. Relationships between MODIS phenological metrics, topographic shade, and anomalous temperature patterns in seasonal deciduous forests of south Brazil. Int J Remote Sens 36:4501-18.

Tuck SL, Phillips HRP, Hintzen RE, Scharlemann JPW, Purvis A, Hudson LN. 2014. MODISTools - downloading and processing MODIS remotely sensed data in R. Ecol Evol 4:4658-68.

Tucker CJ. 1979. Red and photographic infrared linear combinations for monitoring vegetation. Remote Sens Environ $8: 127-50$.

van Leeuwen W, Hartfield K, Miranda M, Meza F. 2013. Trends and ENSO/AAO driven variability in NDVI derived productivity and phenology alongside the Andes mountains. Remote Sens 5:1177-203.

van Schaik CP, Terborgh JW, Wright SJ. 1993. The phenology of tropical forests: adaptive significance and consequences for primary consumers*. Annu Rev Ecol Syst 24:353-77.

Vuolo F, Mattiuzzi M, Klisch A, Atzberger C. 2012. Data service platform for MODIS vegetation indices time series processing at BOKU Vienna: current status and future perspectives. In: Michel U, Civco DL, Ehlers M, Schulz K, Nikolakopoulos KG, Habib S, Messinger D, Maltese A, editors. Proc. SPIE 8538, Earth Resources and Environmental Remote Sensing/GIS Applications III. Vol. 8538. p 85380A.

Wright SJ, van Schaik CP. 1994. Light and the phenology of tropical Trees. Am Nat 143:192-9.

Zimmerman JK, Wright SJ, Calderón O, Pagan MA, Paton S. 2007. Flowering and fruiting phenologies of seasonal and aseasonal neotropical forests: the role of annual changes in irradiance. J Trop Ecol 23:231.

Zuur AF, Ieno EN, Elphick CS. 2010. A protocol for data exploration to avoid common statistical problems. Methods Ecol Evol 1:3-14. 